\title{
ANALISIS PENGARUH PELAYANAN KELUHAN TERHADAP TINGKAT KEPUASAN SISWA PADA SMA 1 PRINGGABAYA LOTIM NTB.
}

\author{
Sri Shanti Ariani \\ Manajemen Pendidikan Islam, STAI Darul Kamal NW Kembang Kerang, NTB \\ Email : srishantiarianiariani@gmail.com
}

\begin{abstract}
Abstraksi
Kepuasan pelanggan (siswa) adalah fungsi dari perbedaan antara kinerja yang dirasakan dengan harapan pelanggan (siswa). Permasalahan yang diteliti dalam penelitian ini adalah bagaimana hubungan pengaruh variabel Bukti Langsung, Keandalan, Daya Tanggap, Empati dan jaminan secara simultan terhadap Tingkat Kepuasan Pelanggan dari variabel Pelayanan Keluhan mana yang berpengaruh dominan terhadap Tingkat Kepuasan Pelanggan.

Jenis penelitian yang digunakaan adalah eksplanatori yaitu menguji hipotesis bahwa terdapat hubungan dan pengaruh dari variabel Pelayanan Keluhan, yaitu: Bukti Langsung, Keandalan, Daya Tanggap, Empati dan Jaminan secara bersamaan terhadap Tingkat Kepuasan siswa dan terdapat salah satu variabel Pelayanan Keluhan yang berpengaruh dominan terhadap Tingkat Kepuasan siswa. Penelitian ini dilaksanakan pada SMA 1 Pringgabaya Lotim NTB dengan mengambil sampel sebanyak 128 orang dari populasi siswa yang melakukan keluhan selama tahun 2020.Teknik Pengumpulan sampel adalah Purposive Samplig.

Dalam analisis dan secara statasistik, digunakan metode analisis korelasi linier berganda dan koefisien regresi berganda pada tinkgat signifikasnsi 0,05 yang diolah komputer dengan menggunakan program SPSS versi 25. Dari hasil analisis dengan metode tersebut dapat dibuktikan bahwa variabel pelayanan keluahan pelanggan (siswa) yaitu: Bukti Langsung, Keandalan, Daya Tanggap, Empati dan Jaminan mempunyai hubungan dan pengaruh yang signifikan secara bersama-sama terhadap tingkat kepuasan pelanggan dengan korelasi berganda (R) sebesar 0,919 yang artinya tingkat keeratan hubungan yang sangat tinggi. Untuk menguji secara bersama-sama antara variabel-variabel bebas dan varibel terikat, diketahui bahwa variabel jaminan merupakan variabel yang paling dominan dengan tingkat $\mathrm{t}$ hitung 2,82.

Jaminan menjadi variabel bebas mempunyai pengaruh yang paling dominan terhadap tingkat kepuasan pelanggan, jaminan pelayanan yang terdiri dari: kepampuan, kepastian dan hasil penaganan keluhan memuaskan pelanggan (siswa) adalah tujuan utama dari penyampaian keluhan pelanggan (siswa). Setiap pelanggan (siswa) menyampaikan keluhan tentu ingin sekali keluhan dapat terselesaikan dengan cepat, akurat dan memuaskan. Jaminan dari suatu pelayanan mempunyai pengaruh terhadapa tingkat konsistensi kerja (performance) dari SMA 1 Pringgabaya Lotim NTB, terlebih lagi jaminan menujukkan kemampuan SMA 1 Pringgabaya Lotim NTB untuk dapat dipercaya pelanggan (siswa).
\end{abstract}

Kata Kunci: analisis, pelayanan keluhan, tingkat kepuasan 


\section{Pendahuluan}

Dalam era globalisasi ini persaingan bisnis menjadi sanga tajam, baik di pasar domestik (nasional) maupun dipasar internasional (global). Salah satu karakteristik utama kegiatan bisnis adalah persaingan. Globalisasi telah merambah semua jenis produk dan jasa dan tidak menyisakan wialayah geografis tertentu, oleh karena itu tidak heran jika dikatakan bisnis masa depan ialah bisnis global.

Pendidikan merupakan faktor yang sangat penting bagi kehidupan manusia, dengan pendidikan manusia mampu menjadi lebih berbudaya dan mampu mengembangkan budaya tersebut demi mencapai kehidupan yang lebih baik, dengan semakin berkualitasnya hidup manusia, manusia dapat mengaktualisasikan dirinya secara terus menerus dalam mempertahankan mutu dan kualitas kea rah yang lebih baik dalam kehidupan bermsayarakat.

Undang-undang Sikdiknas No. 20 tahun 2003, menyatakan bahwa "Pendidikan merupakan usaha sadar dan terencana untuk mengwujudkan suasana belajar dan proses dan pembelajaran agar peserta didik secara aktif mengembangkan potensi dirinya untuk memiliki kekuatan spiritual keagamaan, pengedalian diri, keperibadian, kecerdasan, ahlak mulia, serta keterampilan yang diperlukan dirinya, masyarakat bangsa dan Negara". ${ }^{1}$ Dari pengertian tersebut diatas dapat dimegerti bahwa pendidikan merupakan suatu usaha atau aktivitas untuk memebentuk manusia-manusia yang cerdas dalam berbagai aspeknya, baik intelektual, sosial, emosional maupun spiritual,terampil serta berkepribadian dan dapat berperilaku dengan hiasan ahlak mulia. Oleh karena itu, pendidikan segala upaya pendidikan harus merupakan suatu langkah bagi perwujudan manusia yang baik dalam seluruh dimensinya yang nantinya mampu mengisi kehidupannya secara produktif bagi kepentingan dirinya, masyarakat bangsa dan Negara.

Meskipun Suatu negara memiliki kekuasaan dan kemandirian dalam mengatur serta mengelola sistem pendidikan masing-masing, namun konstelasi kehidupan suatu bangsa tidak dapat mengabaikan berbagai pengaruh internasional dan global yang mau tidak mau akan, sedang dan terus berpengaruh pada bidang pendidikan di semua Negara, sehingga globalisasi dan internasionalisasi pendidikan juga sangat dirasakan termasuk di Indonesia, di mana berbagai kebiajakan pendidikan selalu atau cendrung selalu menjadi dimensi internasional dan global sebagai pertimbangan penting dalam menentukan apa dan bagaimana pendidikan itu dilakasanakan. Perhatian pada mutu layanan pendidikan yang menekankan pada kepuasan siswa, malayani dan mempertahankan mereka.

\footnotetext{
${ }^{1}$ Departemen Pendidikan Nasional, Tentang Sistem Pendidikan Nasional , (Jakarta:Departemen Pendidikan Nasional, $2003,1$.
} 
Peningkatan mutu pendidikan sekolah termasuk di dalamnya mutu layanan perpustakaan dan mutu pengajaran merupakan uapaya-upaya yang harus dilakukan agar kepuasan siswa pelanggan pendidikan dapat diberikan secara optimal. Namun demikian ada beberapa masalah yang dihadapi oleh lembaga pendidikan tinggi di Indonesia pada umumnya, antara lain: rendahnya mutu layanan pendidikan pada sebagian sekolah di Indoneisa menjadi kendala dalam meningkatkan mutu pendidikan nasional, di lain pihak mutu layanan pendidikan mempunyai hubungan dengan kepuasan siswa sebagai pelanggan lembaga pendidikan. Adanya perubahan paradigma dalam proses pembelajaran,yaitu dari teacher cenre learning menjadi student centre learning berdampak pada bagaimana upaya lembaga pendidikan dalam meningkatkan mutu pendidikan di perpustakaa SMA 1 Pringgabaya Lotim NTB, terus berupaya untuk menginkatan jasa pelayanan bagi kepentingan pelanggan dalam mengatisipasi persaingan dengan penyempurnaan dari teknologi sehingga mampu meningkatkan efisiensi kehandalan layanan jasa perpustakaa SMA 1 Pringgabaya Lotim NTB. Guna meningkatkan kualitas serta kemampuan layanan yang berorienasi pada kebutuhan pasar dan kebutuhan pelangga, perpustakaa SMA 1 Pringgabaya Lotim NTB telah mentukan tolak ukur yang digunakan sebagai dasar untuk memudahkan tercapainya sasaran, perpustakaa SMA 1 Pringgabaya Lotim NTB. Tolak ukur yang digunakan antara lain waktu peminjaman buku, tingkat pengembalian buku, sistem denda karena waktu pinjam yang sangat lama, realisasi layanan pengendalian keluhan pelanggan, serta peningktan produktivitas karyawan secara keseluruhan.

Usaha untuk mengwujudkan kepuasan pelanggan bukan hal yang mudah, upaya perbaikan atau penyempurnaan layanan guna mengwujudkan kepuasan pelanggan dapat dilakukan dengan berbagai strategi. Pada prinsipnya kepuasan pelanggan akan menyebabkann para pesaing harus bekerja keras dan memerlukan biaya yang tinggi dalam menarik pelanggan agar tidak pindah ketangan pelanggan yang lain. Salah satu strategi kupuasan pelanggan yang akan dibahas dalam penelitian ini adalah dengan pelayanan keluhan yang baik agar dapat tercapai kepuasan pelanggan. Kualitas pelayanan penanganan keluahan dalam penelitian ini ditentukan oleh lima hal yaitu:

"Bukti langsung (tangibles), keadalan (realibility), daya tanggap (responsiveness), jaminan (assurance) dan empati (emphaty)."2

Pelayanan keluhan penting untuk diperhatikan oleh sekolah, karena pelayanan keluhan yang baik dapat mengakibatkan seorang pelanggan yang semula tidak puas atau kurang puas terhadap produk dari perusahaan dapat menjadi seorang pelanggan yang setia bagi sekolah. Manfaat dari pelayanan keluhan diantaranya:

\footnotetext{
${ }^{2}$ Fandy Tjiptono, Manajemen Jasa, (Yogyakarta:Andi Offset 2004),40.
} 
1. Penyedia jas memperoleh kesempatan lagi memperbaiki hubungan dengan pelanggan yang kecewa.

2. Penyedia jasa terhindar dari publisitas negative.

3. Penyedia jasa akan mengetahui aspek-aspek yang perlu dibenahi dalam pelayanan saat ini.

4. Penyedia jasa akan mengetahui sumber masalah operasinya.

5. Karyawan dapat termotivasi untuk memberikan pelayanan yang berkualitas lebih baik. $^{3}$

Hanya pelanggan yang puas yang akan menjadi loyal kepada sekolah sehingga kelangsungan hidup kampus terjamin. Kepuasan akan tercapai apabila pelayanan yang didapat pelanggan (kinerja yang dirasakan) sesuai dengan harapan. Salah satu strategi untuk meraih kepuasan pelanggan adalah segmen pelayan keluhan yang efektif di mulai dari layanan jasa, dimana kampus menerima keluhan dari pelanggan untuk kemudian menaggapinya dengan menjelaskan bagaimana cara menagani keluhan tersebut, menelitinya, mengatasinya (memerintahkan usaha perbaikan), memeriksa (apakah tindakan perbaikan telah dilaksanakan), menjelaskan (catatan keluhan, sifat tindakan keluhan yang dilakukan), mengelompokkan (analisis stratetegis terhadap keluhan), menyampaikan kepada petugas perpustakaan, menggambarkan (cara-cara untuk menggabungkan data keluhan) yang akan diteruskan kepada, pimpinan SMA 1 Pringgabaya Lotim NTB untuk pembuatan kebiajakan yang akan ditempuh.

Berdasarkan uraian pada latar belakang penelitian ini dapat dirumuskan sebagai berikut: 1). Bagaimana hubungan dan pengaruh variabel pelayanan keluhan meliputi: bukti langsung (X1), keandalan (X2), daya tanggap (X3), jaminan (X4), dan empati (X5) secara bersama terhadap tingkat kepuasan pelanggan (Y). 2). Variabel pelayanan keluhan (X) yang berpengaruh dominan terhadap tingkat kepuasan pelanggan. Tujuan dan kegunaan penelitian ini adalah:1). Untuk menganalisa bagaimana hubungan dan pegaruh secara simultan dari variabel (X1), keandalan (X2), daya tanggap (X3), jaminan (X4), dan empati (X5) secara bersama terhadap tingkat kepuasan pelanggan (Y). 2). Untuk menganalisis Variabel pelayanan keluhan (X) yang berpengaruh dominan terhadap tingkat kepuasan pelanggan.

\section{Kajian Pustaka}

\section{Pengertian Pelayanan Jasa}

Semakin ketatanya persaingan didalam pertumbuhan bisnis jasa, baik itu jasa yang berasal dari sektor pemerintah atau jasa yang berasal dari sektor swasta. Pelanggan akan mempertimbangkan berbagai hal didalam pemeliharaan dan penggunaan jasa yang akan

\footnotetext{
${ }^{3}$ Fandy Tjiptono, Manajemen Jasa, (Yogyakarta:Andi Offset1997), 164.
} 
Jurnal At Tadbir STAI Darul Kamal NW Kembang kerang NTB

Volume 5 No 1 Tahun 2021

P-ISSN : 2580-3433

E-ISSN : 2715-7210

https://journal.staidk.ac.id/index.php/tadbir

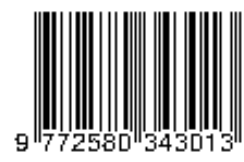

digunakan, tentu saja pelanggan mengaharpkan akan memperoleh kepuasan tersendiri. Jasa adalah setiap tindakan atau kegiatan yang dapat ditawarkan oleh suatu pihak kepada pihak lain, yang pada dasarnya tidak berwujud dan mengabaikan kepemilikan apapun. ${ }^{4}$ Sementara itu menurut American Marketing Assosiation /AMA mendefinisak sebagai berikut:

"Service are separately indentifable, essential intangible activities which provide want satisfaction and that is not necessril ties to the sales of product ornother service. To produce a service may or may not require the use og tangible goods. However when such use required, there is not transfer of title (permanent ownership) to the tangible goods". 5

Jasa atau pelayanan merupakan suatu kinerja penampilan, tidak berwujud dan cepat hilang, lebih dapat dirasakan dariapada dimiliki, serta pelanggan lebih dapat berpartisipasi aktif dalam proses mengkonsumsi jasa tersebut. Dalam srategi pemasaran, definisi jasa harus diamati dengan baik, karena pengertiannya sangat berbeda dengan produk berupa barang. Kondisi cepat lambatnya pertumbuhan jasa akan sangat tergantung pada penilaian pelanggan terhadap kinerja yang ditawarkan oleh pihak produsen. Dari beberapa pengertian tersebut dapat ditarik kesimpulan bahwa pelayanan jasa adalah suatu tindakan yang ditawarkan suatu pihak kepada pihak lain yang membutuhkan dimana tindakan tersebut tidak berwujud dan tidak mengahasilkan kepemilikan apapun.

\section{Karakteristik Pelayanan Jasa}

Bahwa sebagai suatu produk, pelayanan juga memiliki beberapa karakteristik:

1. Tidak berwujud (Intangibility)

Tidak seperti halnya produk fisik, jasa tidak dapat dilihat, dirasa, diraba, didengar atau dicium sebelum jasa itu dibeli.

2. Tidak terpisahkan (Inseparability)

Tidak seperti barang fisik yang diproduksi, disimpan dalam persediaan, didistribusikan melewati berbagai penjualan dan kemudian baru dikomsumsi.

3. Bervariasi (Varaibility)

Diberikan, jasa sangat bervariasi.

4. Mudah lenyap (Perishability)

Jasa tidak bisa disimpan, sifatnya jasa itu mudah lenyap tidak mejadi masalah bila permintaan tetap.

\footnotetext{
${ }^{4}$ Philip Khotler, Manajemen Pemasaran "Edisi Milinium”. (Jakarta:Prenhalingo,2002), 486.

${ }^{5}$ Supranto dkk, Manajemen Pemasaran”Dasar, Konsep dan Strategi”. (Jakarta:Rajawali Pers, 2001), 227.
} 
Jurnal At Tadbir STAI Darul Kamal NW Kembang kerang NTB

Volume 5 No 1 Tahun 2021

P-ISSN : 2580-3433

E-ISSN : 2715-7210

https://journal.staidk.ac.id/index.php/tadbir

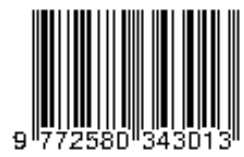

\section{Intagibility}

Jasa berbeda dengan barang, jika barang merupakan suatu objek, alat atau benda, maka jasa adalah suatu perbuatan, kinerja atau usaha. Bila barang dapat dimiliki, maka jasa dapat dikomsumsi tetapi tidak dapat dimiliki. ${ }^{6}$

\section{Metode Penelitian}

Penelitain ini termasuk dalam jenis penelitian eksplanatori atau penjelasan. Hal ini dikarnekan selain mayoritas hubungan penaganan pelayanan keluhan pelanggan dalam hal ini siswa dengan tingkat kepuasan siswa, sekaligus menguji hipotesis yang telah ditetapkan sebelumnya. Metode penelitian kuantitatif yang digunakan untuk mengetahui pengaruh variabel independen (treatmen/perlakuan) terhadap variabel dependen (hasil) dalam kondisi yang dikendalikan. ${ }^{7}$ Kondisi dikendalikan agar tidak ada variabel lain (selain variabel treatment) yang mempengaruhi variabel dependen. Agar kondisi dapat dikendalikan, maka dalam penelitian eksperimen menggunakan kelompok kontrol dan sering penelitian eksperimen dilakukan di labolatorium.

Istilah variabel merupaka istilah yang tidak pernah ketinggalan dalam setiap jenis penelitian. Segala sesuatu yang berbentuk apa saja yang ditetapkan oleh peneliti untuk dipelajari sehingga diperoleh informasi tentang hal tersebut,kemudian diarik kesimpulan. ${ }^{8}$ Adapun dalam penelitian ini variabel bebas dari konsep pelayanan keluhan (X) meliputi 1). Bagaimana hubungan dan pengaruh variable pelayanan keluhan meliputi: bukti langsung (X1), keandalan (X2), daya tanggap (X3), jaminan (X4), dan empati (X5) secara bersama terhadap tingkat kepuasan pelanggan (Y). 2). Sementara itu, variabel terikat dari konsep kepausan pelanggan (Y) dengan hasil perlakuan atau kinerja perpustakaan yang dirasakan mahasisa dengan harapan yang ada pada diri pelanggan tentang pelayanan keluhan yang diberikan perpustakaan di SMA 1 Pringgabaya Lotim NTB.

Populasi adalah keseluruhan element yang akan dijadikan wialayah inferensi/generalisasi. ${ }^{9}$ Populasi dalam penelitian seluruh siswa yang melakukan pengaduan keluhan siswa pada perpustakaan SMA 1 Pringgabaya Lotim NTB adalah sebesar 128 siswa

\footnotetext{
${ }^{6}$ Philip Kotler, Manajemen Pemasaran, (Jakarta:Prenhalindo,2007) , 45

${ }^{7}$ Sugiono, Metode Penelitian Pendidikan “ Kualitatif, Kombinasi, R\&D dan Penelitian Pendidikan)”.,Bandung:Alfabeta,2019), 127

${ }^{8}$ Sugiono, Metode Penelitian Pendidikan "Kuantitatif, kualitatif, Kombinasi, $R \& D$ dan Penelitian Pendidikan". Bandung:Alfabeta,2019), 74

${ }^{9}$ Sugiono, Metode Penelitian Pendidikan "Kuantitatif, kualitatif, Kombinasi, $R \& D$ dan Penelitian Pendidikan". Bandung:Alfabeta, 2019), 145
} 
Jurnal At Tadbir STAI Darul Kamal NW Kembang kerang NTB

Volume 5 No 1 Tahun 2021

P-ISSN : 2580-3433

E-ISSN : 2715-7210

https://journal.staidk.ac.id/index.php/tadbir

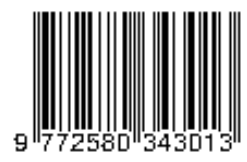

bulan januari samapi desember 2019. Jika hanya akan meneliti sebagian populasi, maka penelitian tersebut penelitian sampel. ${ }^{10}$ Teknik pengambilan sampel dalam penelitian ini adalah Purposive Samping. Sampel bertujuan dilakukan dengan cara mengabil subjek bukan didasarkan atas strata, random atau daerah akan tetapi didasarkan atas dasar tujuan tertentu, ${ }^{11}$ Untuk menentukan jumlah sampel yang diambil pada penleitain ini dengan menggunakan rumus Yamane dan Isac and Michael: $\mathbf{n}=\frac{N}{1+N(e)^{2}}$

$\mathrm{N}=$ Jumlah populasi

$\mathrm{n}=$ Jumlah sampel yang diperlukan

$\mathrm{e}=$ Tingkat kesalahan sampel (sampling error), dalam penelitian ini menggunakan $2 \%$

Jumlah populasi dalam penelitian ini adalah 128 siswa yang melakukan pengaduan pada perpustakaan SMA 1 Pringgabaya Lotim NTB dengan pengambilan sampel 99 dengan hasil pembulatan 100 siswa. Dalam penelitian digunakan beberapa teknik pengumpulan data yaitu: observasi, dokumentasi, wawancara dan kuesioner. Validias adalah suatu ukuran yang menujukan tingkat-tingkat kevaliditas suatu isntrumen. ${ }^{12}$ Valit tidaknya suatu item dapat diketahui dengan membandingkan indeks korelasi produk moment ( $\mathrm{r}$ hitung) dengan probabilitas, pada tingkat signifikasi 0,05 sehingga apabila korelasi yang diperoleh berada diatas probabilitas, berarti item tersebut itu adalah valid. Pengujian validitas untuk tiap pertanyaan dalam kuesioner digunakan program SPSS versi 25 (Statistical Package Social Sciencess) dan apabila dihitun secara manual, maka validitas dapat diperoleh dengan menggunakan rumus Product Moment Pearsen Corelation dengan rumus:

$$
\begin{aligned}
& \mathrm{r}=\frac{S P}{\sqrt{S P} x \sqrt{S S} y} \\
& \text { dimana: } \\
& \mathrm{Sp}=\text { Sum of Product } \\
& \mathrm{SSX}=\text { Samsquare dari variabel } x \\
& \text { Ssy= Samsquare dari variabel } y \\
& \mathrm{r}=\text { Koefisien korelasi } \text { Spearmen }^{13}
\end{aligned}
$$

\footnotetext{
${ }^{10}$ Suharsimi Arikunto, Prosedur Penelitian Suatu Pendekatan Praktek, (Jakarta:PT Rineka Cipta, 2002), 109.

${ }^{11}$ Suharsimi Arikunto, Prosedur Penelitian Suatu Pendekatan Praktek, (Jakarta:PT Rineka Cipta, 2002), 154.

12 Suharsimi Arikunto, Prosedur Penelitian Suatu Pendekatan Praktek, (Jakarta:PT Rineka Cipta, 2002), 144

${ }^{13}$ Mohammad Nazir, Metode Penelitian, (Jakarta:Ghalia,2003), 451
} 
Reliabilitas menujukan pada suatu pengertian bahwa suatu instrument cukup dapat dipercaya untuk dapat digunakan sebagai alat pengumpulan data karena data itu sudah baik, atau dengan kata lain derajat ketepatan, ketelitian atau keakuratan yang ditunjukkan oleh instrument pengukura ${ }^{14}$. Untuk mengetahui suatu alat ukur reliabel atau tidaknya dalam penelitian ini di uji dengan menggunakan Alpha Cronbach $(\propto)$ dengan rumus:

$$
\propto=\frac{K R}{1+(K-1) r}
$$

dimana:

$\propto=$ Reliabilitias

$\mathrm{K}=$ Jumlah item

r=rata-rata koefiesien Korelasi

Suatu instrument dapat dikatakan reliabel bila memiliki koefisien keandalan (reliabilitas) sebesar 0,06 atau lebih. ${ }^{15}$ Setelah data yang diperlukan terkumpul, langkah selanjutnya yang ditempuh peneliti adalah menganalisa data-data tersebut dengan berbagai teknik atau cara-cara yang pada akhirnya memberikan interpretasi atas hasil-hasil analisis. Metode analisis yang digunakan penelitian ini adalah:

\section{1) Analisis Deskriptif}

Analisis ini digunakan untuk mendeskripsikan karakeristik lokasi penelitian, respon yang diteliti, serta didistribusikan item dari masing-masing variabel. Data-data yang telah dikumpulkan selanjutnya diedit dan ditabulaskikan dalam tabel setelah itu dilakukan pembahasan secara deskripif.

2) Analisis Korelasi dan Regresi Liner Berganda

3) Analsis Varian (ANOVA)

4) Koefisien Determinasi

5) Korelasi Pasrsial

6) Regresi Parsial

\footnotetext{
${ }^{14}$ Suharsimi Arikunto, Prosedur Penelitian Suatu Pendekatan Praktek, (Jakarta:PT Rineka Cipta, 2002), 154

${ }^{15}$ Malhotra, Naresh K. 2009. Riset Pemasaran “Pendekatan Terapan”, (Jakarta: PT. Indeks .2009), 308.
} 


\section{Hasil dan Pembahasan}

Adapun pegujian analisis dan interpretasi sebgai berikut:

\section{Pengujian hipotesis pertama}

Sebagaiaman yang telah dirumuskan sebelumnya dalam penelitian sesuai dengan hipotesis: diduga terdapat hubungan dengan pengaruh secara bersama-sama dari variabel bukti langsung (X1), keandalan (X2), daya tanggap (X3), jaminan (X4), dan empati (X5) terhadap tingkat kepuasan siswa $(\mathrm{Y})$. Pengujian ini dilakukan dengan tingkat kepercayaan 95\% atau tingkat signifikansi 5\% $(\propto=0,05)$. Untuk menguji kebenaran hipotesis tersebut digunakan analisis korelasi linier berganda. Pada analis ini digunakan uji ANOVA (F tes) atau uji serentak. Adapun hasil perhitungan yang dilakukan dengan program SPSS 25 dapat dilihat pada tabel 1 sebagai berikut:

\section{Tabel 4}

Rekapitulasi analsisi korelasi dan regresi linier berganda antara variabel-variabel bebas (X) terhadap variabel terikat (Y)

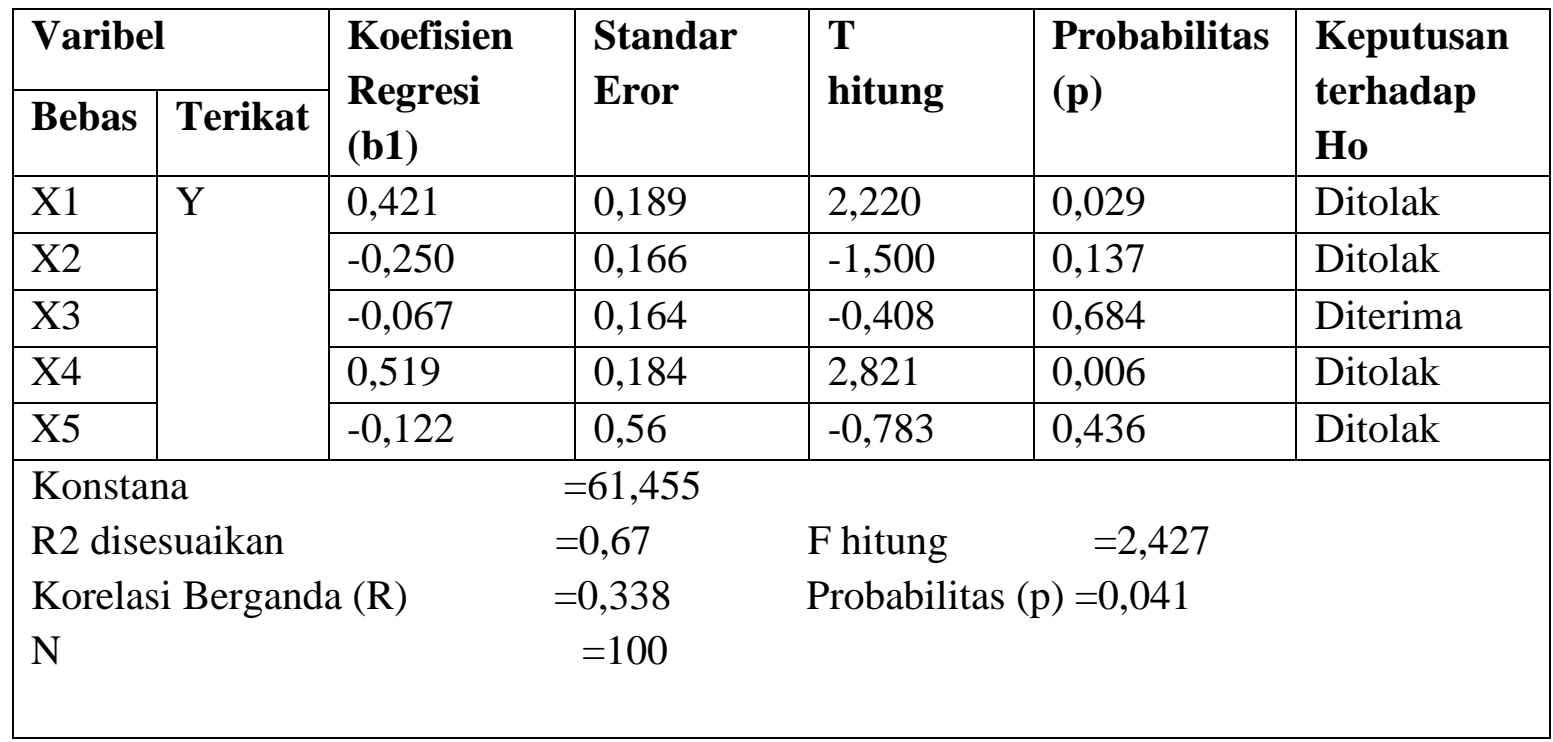

Sumber: Data perhitungan SPSS Versi 25

Dari tabel 4.1 atau melalui ANOVA atau F test, didapat F hitung adalah 2,427 dengan tingkat signifikansi 0,000 karena probabilitas 0,041 jauh lebih kecil dari 0,05, maka model regresi bisa dipakai untuk memperediksi tingkat kepuasan siswa (Y) atau bisa dikatakan bahwa Ho ditolak sehingga hipotesis pertama yang menyatakan terhadap pengaruh secara bersama-sama dari variabel bukti langsung (X1), keandalan (X2), daya 
tanggap (X3), jaminan (X4), dan empati (X5) terhadap tingkat kepuasan pelanggan (Y), dapat diterima.

Besarnya korelasi atau keeratan hubungan antara variabel bukti langsung (X1), keandalan (X2), daya tanggap (X3), jaminan (X4), dan empati (X5) terhadap tingkat kepuasan pelanggan $(\mathrm{Y})$ dapat ditunjukkan dengan angka korelasi berganda $(\mathrm{R})$ yaitu sebesar 0,338. Hal ini menujukkan bahwa terjadi korelasi yang sangat kuat dari kelima variabel bebas $(\mathrm{X})$ tersebut erhadap variabel terikat $(\mathrm{Y})$, karena korelasi mendekati angka 1.

Besarnya sumbangan variabel bukti langsung (X1), keandalan (X2), daya tanggap (X3), jaminan (X4), dan empati (X5) terhadap tingkat kepuasan pelanggan (Y) yang ditunjukkan oleh angka R2 disesuaikan yaitu sebesar 0,67 atau sebesar 67\%. Angka ini menujukkan bahwa variabel bukti langsung (X1), keandalan (X2), daya tanggap (X3), jaminan (X4), dan empati (X5) yang digunakan dalam persamaan regresi ini secara bersama-sama telah mampu memberikan sumbangan atau kontribusi terhadap tingkat kepuasan siswa (Y) sebesar 67\% sedangkan sisanya (100\%-67\%) yaitu 33\% merupakan kontribusi dari variabel lain yang tidak dibahas dalam penelitian ini. Berdasarkan analisis regresi linier yang ditampilkan pada tabel1 maka dapat dihasilkan persamaan regresi sebagai berikut:

$\mathrm{Y}=61,455+0,421 \mathrm{X} 1+(-0,250) \mathrm{X} 2+(-0,067) \times 3+(0,519) \mathrm{X} 4+(-0,122) \mathrm{X} 5$

Interpretasi

Konstant sebesar 61,455 menyatakan bawah jika tidak ada variabel bukti langsung (X1), keandalan (X2), daya tanggap (X3), jaminan (X4), dan empati (X5), maka tingkat kepuasan siswa (Y) adalah 61,455

A Untuk setiap penambahan $1 \%$ variabel bukti langsung (X1) meningkatkan kepuasan siswa (Y) sebesar 0,421 dengan asumsi bahwa, keandalan (X2), daya tanggap (X3), jaminan (X4), dan empati (X5) adalah tetap.

B Untuk setiap penambahan 1\% keandaaln (X2) akan mengurangi kepuasan siswa (Y) sebesar -0,250 dengan asumsi bahwa bukti langsung (X1), daya tanggap (X3), jaminan (X4), dan empati (X5) adalah tetap.

C Untuk setiap penambahan 1\% daya tanggap (X3),akan mengurangi tingkat kepuasan siswa (Y) sebesar -0,067 dengan asumsi bahwa bukti langsung (X), keandalan (X2), jaminan (X4) dan empati (X5) adalah tetap. 
D Untuk setiap penambahan $1 \%$ jaminan (X4) akan meningktkan kepuasan siswa (Y) sebesar 0,519 dengan asumsi bahwa bukti langsung (X1), keandalan (X2), bukti langsung (X3), jaminan (X5) adalah tetap.

E Untuk setiap penambahan $1 \%$ empati (X5) akan mengurangi kepuasan siswa (Y) sebesar -0,122 dengan asumsi bahwa bukti lansgsung (X1), keadalan (X2), daya tanggap (X3), jaminan (X4) adalah tetap.

\section{Pengujian hipotesa ke dua}

Sebagaimana telah dirumuskan sebelumnya bahwa penelitian ini sesuai dengan hipotesis: diduga terdapat salah satu variabel bebas $(\mathrm{X})$ yang berpengaruh dominan terhadap tingka kepuasan siswa (Y).

Pengujian ini dilakukan dengan tingkat kepercayaan $95 \%$ atau tingkat signifikansi $0,05(\propto 0,05)$. Untuk menguji kebenaran hipotesis tersebut digunakan analisis regresi parsial yang menggunakan uji t secara parsial maka pengujian dapat dijelaskan sebagai berikut:

A Variabel bukti langsung (X1)

Dari hasil perhitungan yang dapat dilihat pada tabel 4.1 menujukkan bahwa untuk bukti langsung (X1) mempunyai pengaruh positif dan bermakna terhadap tingkat kepuasan pelanggan, pada tingkat signifikasni 0,05 sehingga Ho ditolak, yang artinya bahwa secara parsial variabel bebas yaitu bukti langsung (X1) benar-benar berpengaruh secara signifikan terhadap variabel terikat yaitu tingkat kepuasan siswa (Y), apabila variabel bebas yang lain konstan. Hal ini dapat dibuktikan dengan besarnya koefisien regresi (b1) sebesar 0,421 dan t hitung sebesar 2,220 ( $>$ t tabel $(\propto=0,05 ;$;n-2) sebesar 1,987$)$ serta probabilitas 0,029 $(\mathrm{p}<0,05)$. Dari hasil pengujian dan analisis tersebut dapat diinterpretasikan bahwa penampilan petugas, fasilitas kantor pelayanan dan kenyamanan ruang baca mempunyai pengaruh yang bermakna terhadap kepuasan siswa.

B Variabel Keandalan (X2)

Dari hasil perhitungan yang dapat dilihat pada tabel 4.2 menujukkan bahwa untuk bukti langsung (X1) mempunyai pengaruh positif dan bermakna terhadap tingkat kepuasan pelanggan, pada tingkat signifikasni 0,05 sehingga Ho ditolak, yang artinya bahwa secara parsial variabel bebas yaitu keandaan (X2) tidak berpengaruh secara signifikan terhadap variabel terikat yaitu tingkat kepuasan siswa (Y), apabila variabel bebas yang lain konstan. Hal ini dapat dibuktikan dengan besarnya koefisien regresi (b1) sebesar -0,250 dan $\mathrm{t}$ hitung sebesar $-1,500(>\mathrm{t}$ tabel $(\propto=0,05 ;$;n-2) sebesar 1,987$)$ serta probabilitas $0,137(\mathrm{p}<0,05)$. Dari hasil pengujian dan analisis tersebut dapat diinterpretasikan bahwa kecepatan, ketepatan (akurasi) dan hasil layanan mempunyai pengaruh yang bermakna terhadap kepuasan siswa.

C Variabel Daya Tanggap (X3) 
Dari hasil perhitungan yang dapat dilihat pada tabel 4.3 menujukkan bahwa untuk daya tanggap (X3) mempunyai pengaruh positif dan bermakna terhadap tingkat kepuasan pelanggan, pada tingkat signifikasni 0,05 sehingga Ho ditolak, yang artinya bahwa secara parsial variabel bebas yaitu daya tanggap (X3) tidak berpengaruh secara signifikan terhadap variabel terikat yaitu tingkat kepuasan siswa (Y), apabila variabel bebas yang lain konstan. Hal ini dapat dibuktikan dengan besarnya koefisien regresi (b1) sebesar 0,670 dan $t$ hitung sebesar $-0,408$ ( $>$ t tabel $(\propto=0,05 ; ; n-2)$ sebesar 1,987 ) serta probabilitas 0,684 $(\mathrm{p}<0,05)$. Dari hasil pengujian dan analisis tersebut dapat diinterpretasikan bahwa ketanggapan petugas dalam memberikan pelayanan keluhan, keiginan membantu siswa dan kesediaan petugas dalam mendengarkan keluhan siswa tidak mempunyai pengaruh yang bermakna terhadap tingkat kepuasan siswa.

D Variabel Jaminan (X4)

Dari hasil perhitungan yang dapat dilihat pada tabel 4.4 menujukkan bahwa untuk jaminan (X4) mempunyai pengaruh positif dan bermakna terhadap tingkat kepuasan pelanggan, pada tingkat signifikasni 0,05 sehingga Ho ditolak, yang artinya bahwa secara parsial variabel bebas yaitu jaminan (X4) benar-benar berpengaruh secara signifikan terhadap variabel terikat yaitu tingkat kepuasan siswa (Y), apabila variabel bebas yang lain konstan. Hal ini dapat dibuktikan dengan besarnya koefisien regresi (b1) sebesar $0,519$ dan $\mathrm{t}$ hitung sebesar 2,821 ( $>\mathrm{t}$ tabel $(\propto=0,05 ; ; \mathrm{n}-2)$ sebesar 1,987$)$ serta probabilitas 0,006 $(\mathrm{p}<0,05)$. Dari hasil pengujian dan analisis tersebut dapat diinterpretasikan bahwa kemampuan dan keterampilan petugas, sikap ramah dan sopan petugas dan jaminan kemudahan prosedur pelayanan mempunyai pengaruh yang bermakna terhadap tingkat kepuasan siswa.

E Variabel Empati (X5)

Dari hasil perhitungan yang dapat dilihat pada tabel 4.5 menujukkan bahwa untuk empati (X5) mempunyai pengaruh positif dan bermakna terhadap tingkat kepuasan pelanggan, pada tingkat signifikasni 0,05 sehingga Ho ditolak, yang artinya bahwa secara parsial variabel bebas yaitu emapti (X5) tidak berpengaruh secara signifikan terhadap variabel terikat yaitu tingkat kepuasan siswa (Y), apabila variabel bebas yang lain konstan. Hal ini dapat dibuktikan dengan besarnya koefisien regresi (b1) sebesar -0,122 dan t hitung sebesar $-0,783(>\mathrm{t}$ tabel $(\propto=0,05 ; ; \mathrm{n}-2)$ sebesar 1,987$)$ serta probabilitas $0,436(\mathrm{p}<$ 0,05). Dari hasil pengujian dan analisis tersebut dapat diinterpretasikan bahwa kemampuan memahami keluhan siswa, kemudahan dalam melakukan hubungan dengan petugas dan kepedulian serta perhatian petugas kepada siswa mempunyai pengaruh yang bermakna terhadap tingkat kepuasan siswa. 
Berdasarkan penjelasan diatas, dapt diketahui bahwa variabel jaminan (X4) mempunyai pengaruh yang dominan terhadap tingkat kepuasan siswa $(Y)$ dengan nilai t hitung terbesar yaitu 2,821 .

Jadi dapat disimpulkan bahwa dari kelima variabel bebas penelitan variabel jaminan (X4) yang mempuyai pengaruh paling dominan terhadap tingkat kepuasan siswa (Y). Alasan jaminan menjadi variabel yang mempunyai pengaruh yang paling dominan terhadap tingkat kepuasan pelanggan, karena jaminan pelayanan anatara lain: kemampuan, kepastian dan kesopanan adalah tujuan utama dari penyampain keluhan siswa. Setiap siswa menyampaikan keluhannya tentu ingin sekali keluhannya dapat terselesaikan dengan cepat, akurat dan memuaskan. Jaminan dari suatu pelayanan mempunyai pengaruh terhadap konssitensi kerja (performance) dari sekolah, terlebih lagi jaminan menujukkan kemampuan sekolah untuk dapat dipercaya oleh siswa. Dengan kepercayaan yang diberikan pelanggan, akan mendorong sekolah SMA 1 pringgabaya untuk berusaha memberikan yang terbaik bagi siswa.

\section{Kesimpulan}

Kesimpulan dari hasil penelitian tentang pengaruh pelayanan keluhan terhadap ingkat kepuasan siswa pada perpustakaan SMA 1 Pringgabaya Lotim NTB sebagai berikut:

1. Tingkat kepuasan siswa yaitu perbandingan gap (kesenjangan) hasil persepsi kinerja sekolah yang dirasakan siswa dengan harapan yang ada pada diri siswa tentang pelayanan yang diberikan sekolah.

2. Berdasarkan hasil pengujian yang dilakukan dengan analisis korelasi dan regresi berganda, menujukkan bahwa secara bersama-sama variabel bebasa yaitu bukti langsung, daya tanggap, keandalan, jaminan dan empati mempuyai hubungan yang signifikan dengan variabel terikat, yaitu tingkat kepuasan siswa.

3. Dari koefisien determinsi, ternyata besarnya sumbangan variabel buki langsung, daya tanggap, keandalan, jaminan dan empati terhadp tingkat kepuasan pelanggan adalah sebesar 0,67 atau sebesar $67 \%$, artinya bahwa perubahan tingkat kepausan pelanggan akan dijelaskan oleh kelima variabel bebas yaitu bukti langsung, daya tanggap, keandalan, jaminan dan empati. Sementara itu sisanya sebesar 3,3\% perusahaan variabel tingkat kepuasan siswa akan dijelaskan oleh variabel-variabel bebas yang lain tidak dibahas dalam penelitian ini.

4. Berdasarkan hasil pengujian yang dilakukan dengan analsisi regresi berganda menujukkan bahwa secara bersama-sama variabel bukti langsung, daya anggap, keandalan, jaminan dan empati mempunyai pengaruh yang sangat signifikan terhadp tingakt kepuasan siswa.

5. Berdasarkan hasil pengujian yang dilakukan dengan analisis regresi parsial yang menggunakan probabilias menujukkan bahwa secara parsial yang variabel bukti langsung, 
daya tangap, keandalan, jaminan dan empati mempunyi pengaruh yang signifikan terhdap tingkat kepaudan pelanggan.

6. Dari hasil pengujian diketahui bahwa variabel jaminan (X4) mempunyai pengaruh dominan terhadap tingakt kepuasan pelanggan. Hal ini disebabkan variabel jaminan sangat berkaitn dengan konsistensi kerja (performance) sekolah dan kemapuan untuk dipercaya (dependability) dalam memberikan pelayanan kepada siswa. Apabila keandalan ini tdiak sesuai dengan yang diharpkan siswa maka siswa meras tidak puas.

7. Dari penjelasan yang dikemukakan diatas, maka penelitian ini berhasil membukikan bahwa bukti langsung, daya tanggap, keandalan, jaminan, empati dan bukti langsung mempuyai pegaruh yang signifikan terhadap tingakt kepuasan pelanggan Dengan demikian hipotesis yang menyebutkan bahwa terdapat pengaruh secara bersama-sama dari variabel bukti langsung (X1), keandalan (X2), daya tanggap (X3), jaminan (X4), dan empati (X5) terhadap tingkat kepuasan pelanggan (Y), dapat diterima dan varibel yang berpengaruh dominan adalah jaminan (X4).

\section{Saran}

1. Sekolah perlu untuk melakukan monitoring terhadap kecepatan dan ketepatan waktu penyelesaian penanganan keluhan yang dilaksanakan petugas dilapangan, apakah telah sesuai dengan target penyelesaian penanganan keluhan yang telah ditetapkan sekolah.

2. Sekolah perlu untuk meningkakan kinerja karyawan perpustakaan, karena karyawan perpustakaan merupakan bagian terpenting dalm memberikan layanan keluhan yang efektif diperpustakaan SMA 1 Pringgabaya Lotim NTB, maka mereka perlu mendapatkan dukungan dari semua pihak.

3. Sekolah perlu memberikan perhatian secara khusus kepada penanganan keluhan siswa yang antara lain dengan pemberian kemudahan prosedur pelayanan keluhan bagis siwa, melakukan penambahan fsilitas-fasilitas penunjang pelayanan keluhan siswa dan melakukan penambahan petugas dalam menagani keluhan dilapangan sehingga keluhan yang dialami para siswa yang menggunakan jasa perpustakaan SMA 1 Pringgabaya Lotim NTB dapat diselesaikan dengan cepat, akurat dan memuaskan.

\section{Daftar Pustaka}

Arikunto Suharsimi. 2002. Perosedur Penelitian. Jakarta: PT. Rineka Cipta.

Departemen Pendidikan Naional, (2003). Undang-undang Repobelik Indonesia No.20 Tahun 2003, tentang Sistem Pendidikan NasionL, Jakara:Departemen Pendidikan Nasional.

Kotler Philip. 2007. Manajemen Pemasaran. Terjemahan, Benyamin Molan. Jakarta: PT. Indeks Kelompok Gramedia. 
Kotler, Philip dan A.B. Susanto. 2001. Menejemen Pemasaran di Indonesia. Terjemahan, Benyamin Molan. Jakarta: PT. Indeks.

Kuncoro, Mudrajad. 2001. Metode Kuantitatif Teori dan Aplikasi untuk Bisnis dan Ekonomi. Yogyakarta: Unit Penerbit dan Percetakan AMP YKPN.

Malhotra, Naresh K. 2009. Riset Pemasaran (Pendekatan Terapan). Jakarta: PT. Indeks .

Nazir. 2003. Metode Penelitian. Jakarta: Ghalia Indonesia.

Priyatno, Dwi. 2008. Mandiri Belajar SPSS. Jakarta: Media Com.

Sugiono. 2019. Metode Penelitian Pendidikan (Kuantitatif, kualitatif, Kombinasi, R\&D dan Penelitian Pendidikan). Bandung:Alfabeta.

Tjiptono, Fandy 1997. Strategi Pemasaran. Yogyakart: Andi. 